\title{
PHYSICAL ACTIVITY LEVEL OF FACEBOOK USERS
}

\author{
NIVELL DEATIVIDADE FÍSICA DOS USUÁRIOS DO FACEBOOK
}

NIVEL DEACTIVIDAD FISICA DE LOS USUARIOS DE FACEBOOK

Original Article

Artigo Original

Artículo Original
Fábio Paschoal Júnior ${ }^{1,2}$ (DD (Electrical Engineer)

Gabriel Vinicius Silva Ribeiro² (ID (Internet Systems Technologist) Leandro Moniz de Aragão Daquer² (iD (Internet Systems Technologist)

Renato Campos Mauro² (ID (Systems Engineering and Computer Science)

Eduardo Soares Ogasawara² (iD (Systems Engineering and Computer Science)

Nelson Francisco Favilla Ebecken' (iD (Civil Engineer)

1. Universidade Federal do Rio de Janeiro (UFRJ), COPPE (NTT), Rio de Janeiro, RJ, Brazil.

2. CEFET/RJ, School of Information and Computer Science (EIC), Information Technology Department (DEPIN), Rio de Janeiro, RJ, Brazil.

\section{Correspondence:}

Fábio Paschoal Júnior

CEFET/RJ, Campus Maracanã, EIC/ DEPIN/COINFO.

Av. Maracanã, 229, Rio de Janeiro,

RJ, Brazil. 20271-110.

fabiopjr@yahoo.com.br

\section{ABSTRACT}

Introduction: Interactions of Facebook users led to a study of the influence that users can exert on behavioral changes for a healthier life. Objective: To analyze the behavior of Facebook users in order to define the Users' Behavioral Patterns, by monitoring the practice of physical activities shared online, aided by a social competition among users, with the aim of combating sedentarism through the modern attraction of technology and gamification. Methods: A computational tool was developed to extract data from physical activity shared online. The tool, named FitRank, has permissions to access users' data. Tables and classifications were generated based on an analysis of the data in the database, using decision tree algorithms and descriptive statistical analysis. Results: users were classified according to sociodemographic data, and data on the creation of competitive rankings and the practice of physical activities, including the definition of the User's Behavioral Pattern. Conclusion: The study suggested the importance of technological innovations to combat sedentarism, in line with current social entertainment technologies to make them more enjoyable and motivating for the regular practice of physical activities and to provide a better quality of life. Level of Evidence II; Retrospective study.

Keywords: Sedentary behavior; Sports; Physical activities; Quality of life; Healthcare.

\section{RESUMO}

Introdução: As interações dos usuários do Facebook permitem o estudo da influência que os usuários podem exercer na mudança comportamental para uma vida mais saudável. Objetivo: Analisar o comportamento dos usuários do Facebook para definir o Padrão Comportamental do Usuário, por meio do monitoramento da prática de atividades físicas compartilhadas, auxiliado pela competição social entre usuários, de forma a combater o sedentarismo com o atrativo moderno da tecnologia e da gamificação. Métodos: Foi desenvolvida uma ferramenta computacional de extração de dados dos compartilhamentos de atividades físicas, denominada FitRank, com permissões de acesso aos dados dos usuários. Os quadros e classificações foram gerados a partir da análise das informações coletadas no banco de dados, com o uso de algoritmos de árvores de decisões e aplicando análise estatística descritiva. Resultados: Os usuários foram classificados de acordo com os dados sociodemográficos, os dados de criação de rankings competitivos e com os dados da prática de atividades físicas, incluindo a definição do Padrão Comportamental do Usuário. Conclusão: O estudo sugeriu a importância de inovações tecnológicas no combate ao sedentarismo, de forma sintonizada com as atuais tecnologias de entretenimento social, para tornar mais prazerosa e motivadora a prática regular de atividades físicas e proporcionar qualidade de vida melhor. Nível de evidência ll; Estudo retrospectivo.

Descritores: Comportamento sedentário; Esportes; Exercício físico; Qualidade de vida; Cuidados de saúde.

\section{RESUMEN}

Introducción: Las interacciones de los usuarios de Facebook permiten el estudio de la influencia que los usuarios pueden ejercer en el cambio comportamental para una vida más saludable. Objetivo: Analizar el comportamiento de los usuarios de Facebook para definir el Patrón Comportamental del Usuario, a través de la monitorización de la práctica de actividades físicas compartidas, auxiliado por la competición social entre usuarios, de forma que se combata el sedentarismo con el atractivo moderno de tecnología y de la gamificación. Métodos: Fue desarrollada una herramienta computacional para la extracción de datos de las publicaciones de actividades físicas, denominada FitRank, con autorizaciones de acceso a los datos de los usuarios. Los cuadros y clasificaciones fueron generadas a partir del análisis de las informaciones colectadas en el banco de datos, con el uso de algoritmos de árboles de decisión y aplicando análisis estadístico descriptivo. Resultados: Los usuarios fueron clasificados de acuerdo con los datos sociodemográficos, los datos de creación de rankings competitivos y datos de la práctica de las actividades físicas, incluyendo la definición del Patrón Comportamental del Usuario. Conclusión: El estudio sugirió la importancia de innovaciones tecnológicas en el combate al sedentarismo, de forma sincronizada con las actuales tecnologías de entretenimiento social, para que sea más placentera y motivadora la práctica regular de actividades físicas y proporcionar calidad de vida mejor. Nivel de evidencia Il; Estudio retrospectivo.

Descriptores: Conducta sedentaria; Deportes; Ejercicio físico; Calidad de vida; Cuidado de la salud. 


\section{INTRODUCTION}

Online Social Networks (OSN) are already part of our daily lives. Among OSN, Facebook stands out, usually offering new forms of interaction. 'These interactions allow researchers to observe the behavior of users, ${ }^{2}$ including the motivation or influence that they can have on other people regarding behavioral changes. ${ }^{3}$ Facebook has many users and currently is the largest OSN. ${ }^{4}$

Online socialization is increasing and becoming more and more intense, with positive or negative reactions and emotional contagion. ${ }^{5-7}$ This emotional contagion can be positive, through behavioral change for a healthy life. ${ }^{8,9}$ It can be also negative, with the exposure of intolerances, violence or illegal situations.

Social Media Apps (SMP) are software that enables sharing new experiences and content on OSN profiles. Its use on smartphones improves these contents, especially when integrated with technologies such as heart monitor, smart sports wristbands, GPS, smartwatches, sensors, gyroscope and accelerometer. ${ }^{10}$

Thus, the aim of this study was to develop a framework capable of monitoring and enabling the analysis of users' behavior on Facebook, ${ }^{11}$ who use these type of technology, in order to define their Standard Behavior Pattern. 3,8,9,12,13 This analysis was carried out by monitoring the practice of shared physical activities on social media. For this, we developed FitRank, an app integrated with Facebook, which extracts the information for monitoring.

The links for FitRank are: http://eic.cefet-rj.br/app/FitRank/ or https:// www.facebook.com/fitrank.go/. Its goal is to promote a social competition between users, based on the sharing of rankings related to physical activities. These activities comprise walking, jogging and biking, which are monitored, shared and integrated on Social Apps.

Another FitRank's goal is to motivate and stimulate users to combat sedentary lifestyle. Fighting a sedentary lifestyle is important at all stages of life. ${ }^{14}$ With FitRank, this happens through a gamification approach, with the modern appeal of OSN and physical activity apps. This gamification can be triggered by a healthy social competition among users, stimulating the regular practice of physical activities. ${ }^{15}$

With this gamification, we can expect a higher level of socialization among users, which can be achieved by emotional contagion and competitive spirit. Emotional contagion can be understood by the social support among these users, improving their levels of subjective well-being. ${ }^{5}$ Sharing physical activity rankings is a good example, since they help to improve the quality of life., $3,9,13$

Moreover, with its dissemination, it is expected that FitRank may become a support tool for combating sedentary lifestyle. It may act as a motivator for the practice of physical ${ }^{10}$ activities, which can reduce the costs of public and private health systems, considering the diseases related to a sedentary lifestyle. In addition, it can be a mechanism to reduce barriers to the practice of exercises.

This dissemination may occur due to the following reasons. The first is the low risk of injuries in outdoor physical activities, even considering that the knee joint is very susceptible to injury. ${ }^{16,17}$ The second is having access to an appropriate place for physical activities, ${ }^{18,19}$ with an infrastructure that can support this practice ${ }^{19,20}$, promoting well-being and safety. ${ }^{19}$ The third reason is that the regular practice of physical activities can be perceived as a health issue. ${ }^{11,19,21-26}$ Finally, we must consider the way of motivating and maintaining the practice of physical exercises, including tools to set up a safety and healthy exercise program. ${ }^{28}$

\section{MATERIALS AND METHODS}

This study used data collected from FitRank users' profiles on Facebook. The collection was done with authorization from Facebook and
FitRank users. ${ }^{8}$ Privacy was fully respected; we used summarized data and did not identify users.

The Facebook's authorization consisted of the permission to FitRank to access data related to the sharing of physical activities. Facebook granted this access after their analysis, and FitRank had the approval, considering all the ethical issues described by the social network.

The authorization of users was exclusively with "Login into Facebook." In the first time, access permissions to the user's public profile are requested, including friends list, email address, and physical activities. All these permissions can be granted or denied, guaranteeing that Facebook users become FitRank users in a consensual way. Thus, the users of this study electronically signed the informed consent form in the first access to FitRank. At any time they can easily quit FitRank, unlinking it from their Facebook account.

Figure 1 shows FitRank's Architecture. The user does physical activities monitored by the app and shares them on Facebook. FitRank collects this information by storing them in a database via RestFB. When the user or his or her friends access FitRank and create a ranking, these data will be considered.

The data collection process is done in the ranking generation, and the information from users and their friends is both extracted. With this, data update occurs when he/she or a friend creates a ranking, which allows updating them more frequently.

The users of this study was initially estimated at 378: 292 men (77\%), and 86 women (23\%), being the total of all FitRank users. In the first data analysis, this population was reduced to samples of users who created valid rankings, that is, they built them according to the modalities of physical activities practiced. The sample that met these criteria had 125 individuals: 98 men (78\%), and 27 women (22\%), being the one considered in the study. The prevalence of men in the samples was also observed in other studies. ${ }^{16,17,19}$

We adopted this selection criteria because the information of generated rankings was compared, excluding those that had rankings without any activities. Concerning invalid ranking data, out of the 253 users - 194 men (77\%) and 59 women (23\%) -, 188 (fitness lifestyle) had shared physical activities - 147 men (78\%) and 41 women (22\%) -, but they were excluded from this study because they did not create a ranking according to their physical activities: for instance, a biker who establishes

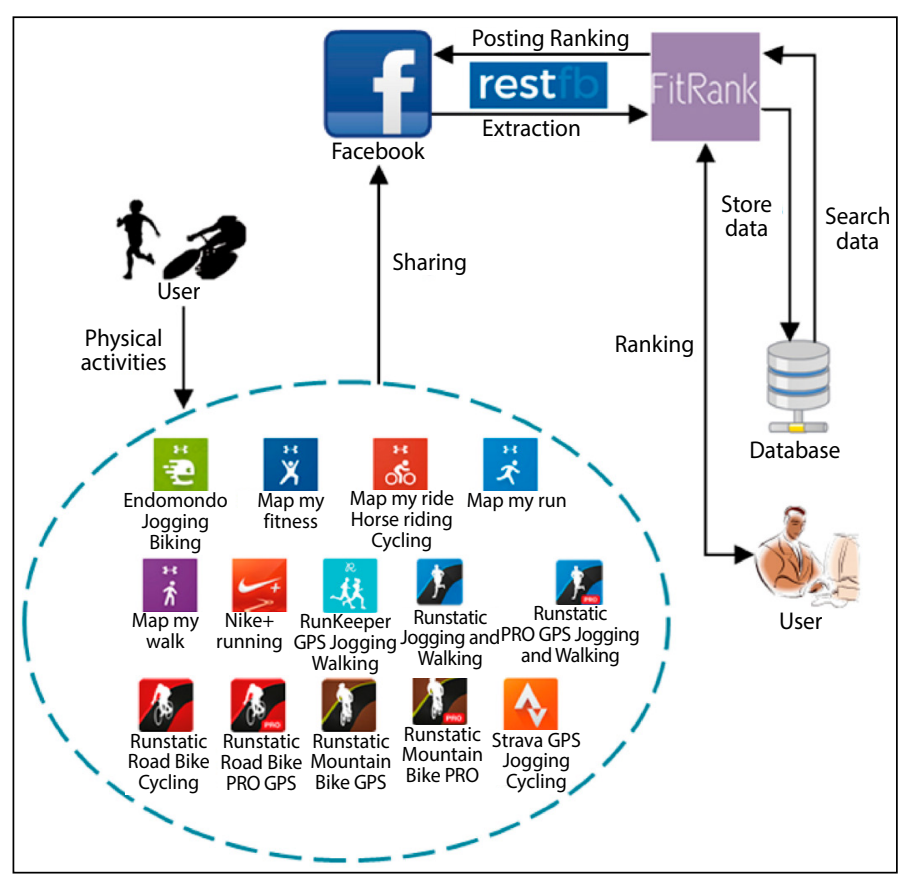

Figure 1. FitRank's architecture. 
only a jogging ranking. The other 65 users (non-fitness lifestyle) shared no physical activities - 47 men (72\%) and 18 women (28\%) -, being in this case outside the scope of FitRank.

The tables and classifications of our study were created and established with decision tree algorithms, implemented in $\mathrm{R}$, and also with tools for building graphs and based on descriptive statistical analysis.

\section{RESULTS}

Figure 2 summarizes sociodemographic data. Some values were described as "unspecified"to represent the absence of information. Zero values indicate the lack of occurrence of the respective value.

The age group in (a) suggests a balance in the ranges 18 to 39 or 40 to 60 , with a slight predominance of the former. The age group represented by zero indicates those who declared only month and day of birth. We also noted the presence of minors and older adults, and a concentration of men in the range between 18 and 39 years, and women in the 40 to 60 years age group.

The Brazilian geographic regions indicated in (b) show a concentration in the Southeast region. The South region has the second highest concentration, but much lower than the Southeast. We found a balance for the other regions and absence of users from the North region.

The schooling in (c) suggests a concentration of users with higher education. "Complete high school"has the second highest concentration, but lower than "higher education."We highlight the lack of information on this topic.

The marital status in (d) indicates a majority of married users. The single status had the second highest concentration, a percentage close to that of married. We also highlight the lack of information on this topic. An interesting fact was the concentration of married men and single women: this is positive, since some studies indicate the importance of the influence of parents' physical activity level on their children. ${ }^{29,30}$

Figure 3 summarizes the ranking creation data. The Amount of Rankings in (a) shows a concentration in the range of one to ten rankings. The range of 21 to 40 rankings had the second highest concentration, but well below that of one to ten. There was a balance for the other rankings.

Ranking configurations in (b) suggest a concentration between two to five settings of different configurations. FitRank offers up to 60 different configurations. They are created combining different physical activities (walking, jogging, biking or mixed, that is, walking + jogging + biking) with classification criteria (distance, average speed or number of activities) and period (day, week, month, year or the entire publication period).

People in the rankings in (c) suggest a concentration between two and five. This means that the rankings include the user and up to four friends, indicating a good level of socialization among them. However, we found a significant number of users without friends, i.e., alone in the ranking.

The grouping of Modalities versus Types in (d) summarizes the information of the rankings created $(n=2,572)$. All the selected modalities and types are indicated. We observed a higher concentration of jogging rankings. Mixed rankings and biking rankings are the second and third, respectively. The walking rankings had low occurrence.

Figure 4 summarizes data related to physical activity. In this study, we made a new selection of users from the 125 previously chosen, separating only those who had shared physical activities before and after the use of FitRank. Considering these criteria, the sample was reduced from 125 to 111 users $(n=111)$.

The grouping of Modalities versus Types in (a) summarizes the information of the rankings created $(n=17,816)$. All the selected modalities and types are indicated. We found a concentration on biking, and jogging was the second most common.

The History of Physical Activities in (b) reveals the sharing of physical activities in a continuous period of up to four years. There is also a significant concentration of up to two years. These data suggest that the physical activities have been practiced for a significant period.

The time using FitRank in (c) shows a continuous period of up to six months. The continuous period of seven to twelve months had the

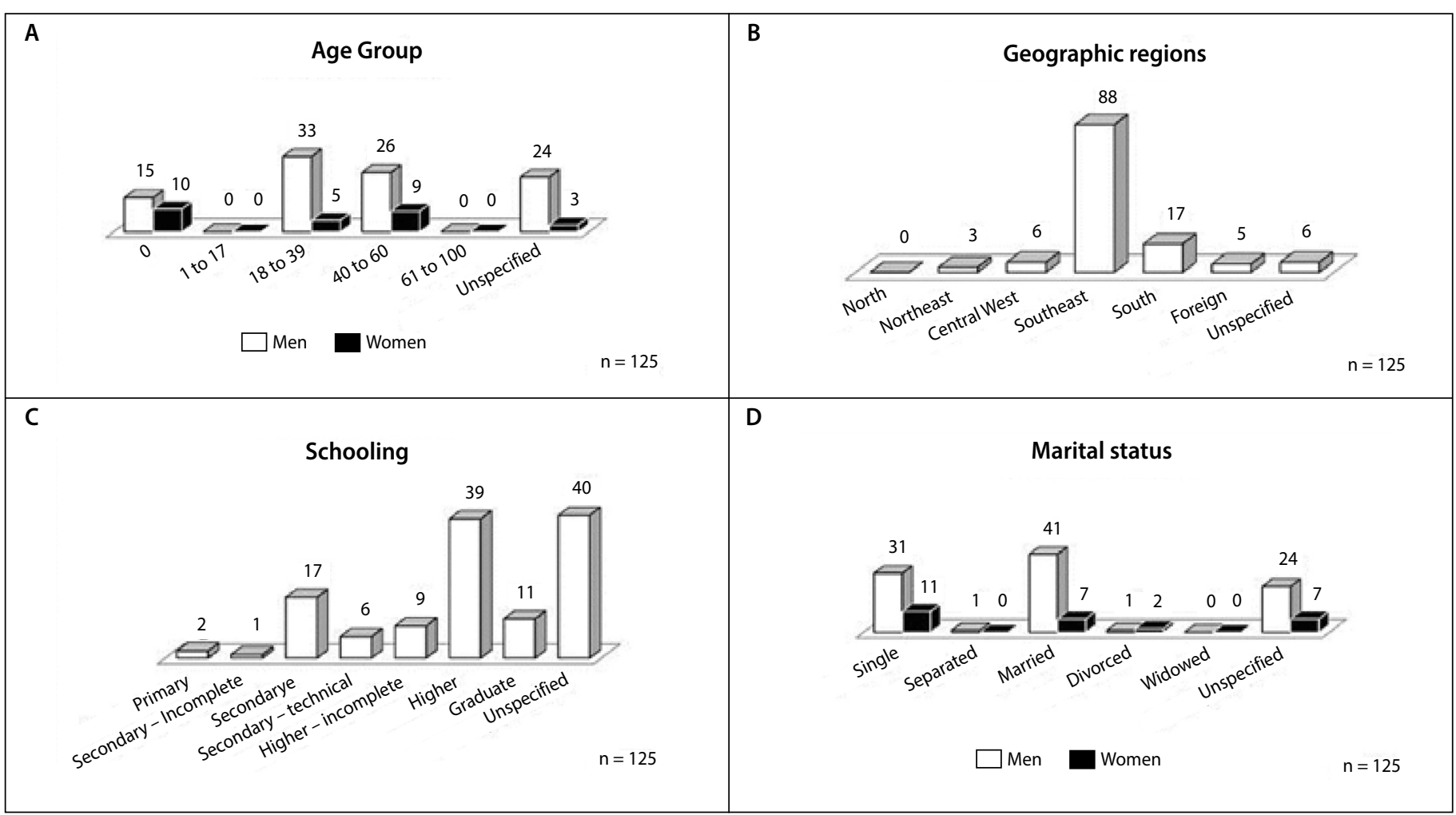

Figure 2. Sociodemographic information. 
second-highest concentration. These concentrations suggest that FitRank have been recently used.

The comparison of the activities Previously $\times$ Subsequent to the use of FitRank in (d) indicates a concentration with up to 50 previous and subsequent activities. There is a balance for other concentrations up to the limit of 400 previous and subsequent activities. These concentrations suggest that FitRank have been recently used.
Finally, the users' behavior pattern ( $n=111$ ) was classified according to the frequency of physical activity (Figure 5). They were classified according to the modality of physical activity. When a user practiced more than one modality, he or she was classified by order of frequency. An example is the class "Jogger Biker Walker," in which the most to the less frequent activities are jogging, biking and walking.

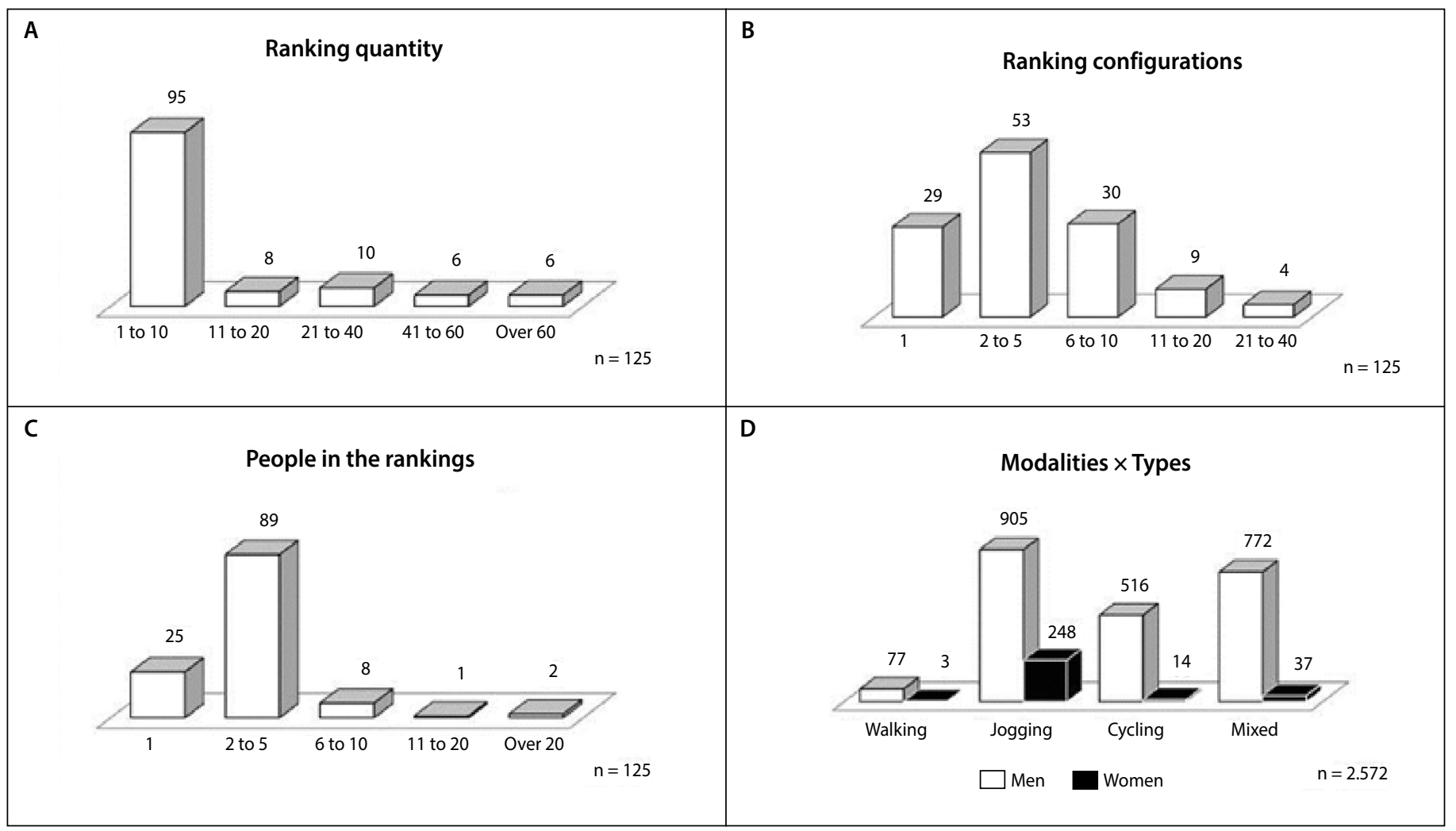

Figure 3. Ranking information generated.

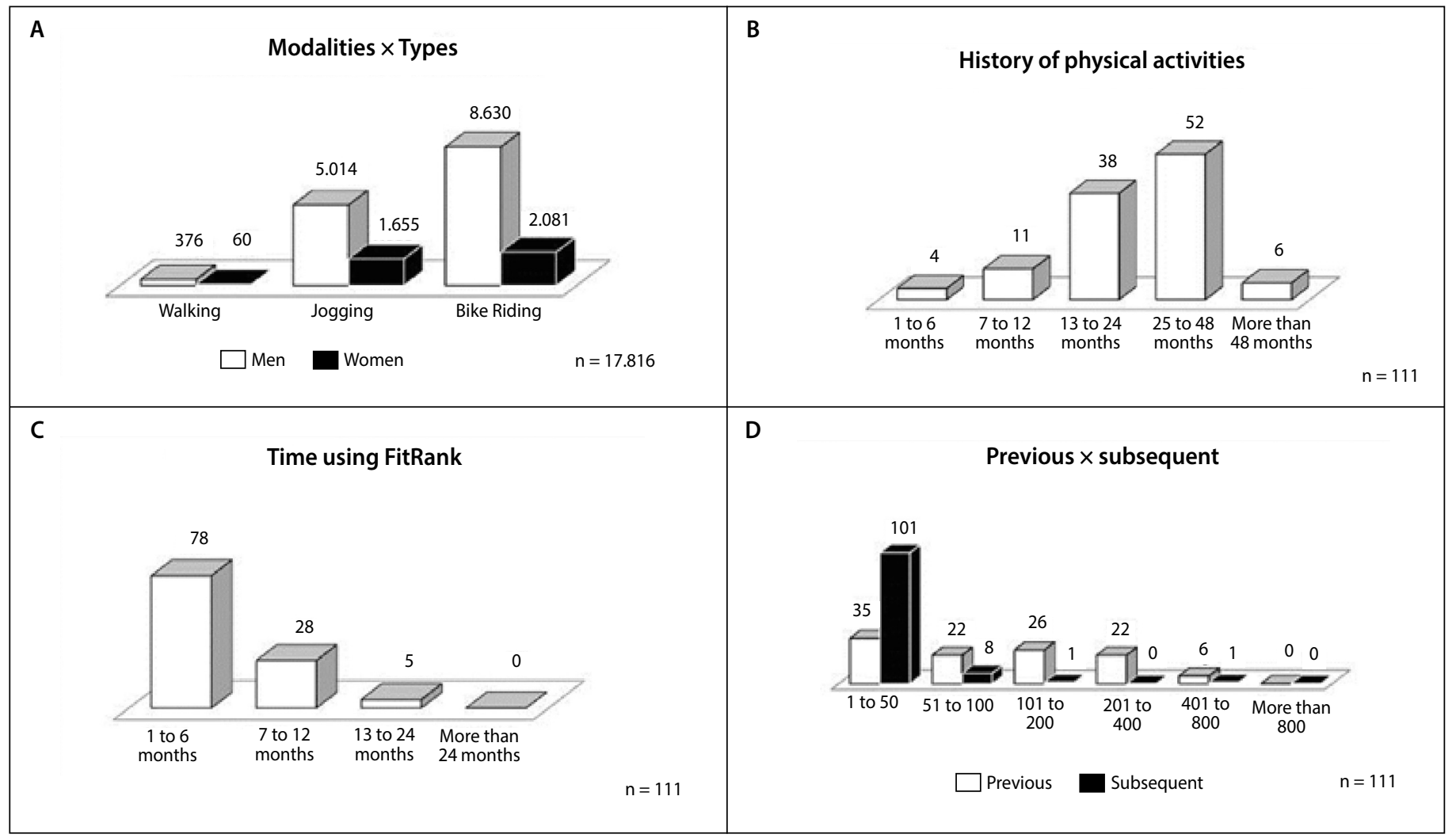

Figure 4. Information on physical activity. 


\section{Users' Behavior Pattern}

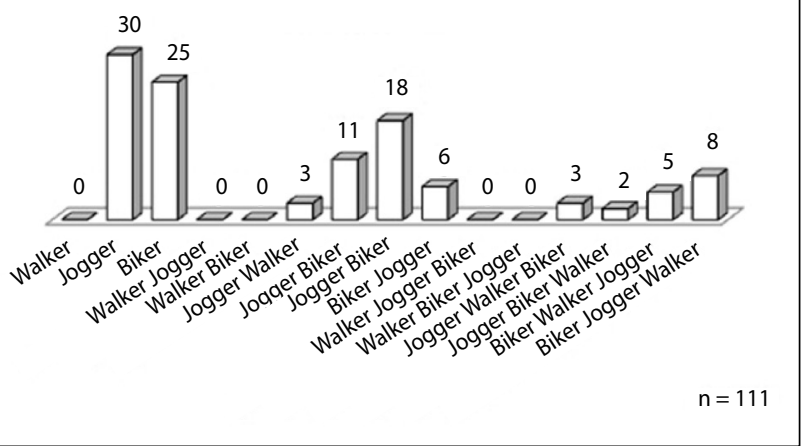

Figure 5. Users' Behavior Pattern.

\section{DISCUSSION}

With the data analysis, it was possible to infer the user's profile pattern through higher frequencies. He or she is between 18 and 39 years old, lives in the Brazilian Southeast region, has higher education and is married. The user created up to 10 rankings, experimented from two to five different ranking settings, had up to four friends in them, being jogging his or her main ranking modality. The user's physical activities focused more on biking, and he or she shares his activities on the profile for at least two consecutive years, with a limit of up to four consecutive years; in addition, he or she uses FitRank from one to six months, and the most frequent physical activities are those he or she already practiced before using FitRank.

Some interesting differences emerged in this study. Regarding marital status, men were predominantly married and women single. Regarding age group, there was a predominance of men between 18 and 39 years, and women between 40 and 60 years.

Although the number of jogging rankings was higher and the number of joggers greater than the bikers in the sample, biking had higher frequency than jogging. This may indicate that bikers do more physical activities than joggers, with shorter intervals between physical activities.

Even though most FitRank users are recent, we perceive a good level of socialization (up to four friends). With the dissemination of FitRank, currently limited to sponsored posts on Facebook or invitations in groups, greater socialization and greater balance in the modalities of physical activities are expected.

The target audience of this study were Facebook users who shared physical activities on social apps for physical activity monitoring, in specific walks, runs and bike rides, and who use FitRank. Thus, those considered to be outside the scope of FitRank (non-fitness lifestyle), represented by 65 users (17\% of the total sample of this study), may have practiced physical activities and not shared them on their profiles.

This study represents a very small audience of Facebook users and does not express their overall behavior, showing only those who share their own physical activities. Future studies would be necessary to deepen both classifications and predictions of behaviors.

In a new study, the plan is to develop classifications of users considering effort levels of physical activities and correlating them to the amount of Metabolic Equivalents (METs) for the classification and prediction of user's behavior, according to recommendations of the World Health Organization. ${ }^{9}$

\section{CONCLUSIONS}

This study pointed out the importance of technological innovations in combating sedentary lifestyle, based on current social media, in order to make the regular practice of physical activities more pleasurable and motivating, and to promote a better quality of life.

\section{ACKNOWLEDGMENTS}

We would like to thank the National Council for Scientific Development (CNPq) for granting a master's degree scholarship.

All authors declare no potential conflict of interest related to this article

AUTHORS' CONTRIBUTIONS: Each author made significant individual contributions to this manuscript. FPJ: participated in the conception of the study proposal, the development of the FitRank, collection and analysis of the data and writing and review of the manuscript, GVSR, LMAD and RCM: participated in the development of the FitRank and the data collection, ESO and NFFE: participated in the concept of the study proposal and the review of the manuscript. All authors read and approved the final version of the manuscript.

\section{REFERENCES}

1. Joinson AN. Looking at, looking up or keeping up with people?: Motives and use of Facebook. Proceedings of the SIGCHI Conference on Human Factors in Computing Systems. 2008:1027-36.

2. Kraft P, Drozd F, Olsen E. Digital Therapy: Addressing Willpower as Part of the Cognitive-Affective Processing System in the Service of Habit Change. Persuasive. 2008:177-88

3. Paschoal F, Ebecken NFF, Ribeiro GVS, Daquer LMA, Mauro RC, Ogasasawara ES. Healthy behavior with social apps: Proposal for evolution study of the use of fitness social apps on Facebook. 2016 11 th Iberian Conference on Information Systems and Technologies (CISTI) 1-6. 2016.

4. Cosenza V. World Map of Social Networks. 2020 [Acesso em: 17/09/2020]. Disponível em: http:// vincos.it/world-map-of-social-networks/

5. Yu E, Kim HC. Is she really happy? A dual-path model of narcissistic self-presentation outcomes for female facebook users. Comput Hum Behav. 2020;108:106328.

6. Brailovskaia J, Ströse F, Schillack H, Margraf J. Less Facebook use - More well-being and a healthier lifestyle? An experimental intervention study. Comput Hum Behav. 2020;108:106332.

7. Jenkins RH, Shen C, Dumontheil I, Thomas MSC, Elliott P, Roosli M, et al. Social networking site use in young adolescents: Association with health-related quality of life and behavioural difficulties. Comput Hum Behav. 2020;109:106320.

8. Paschoal F, Ebecken NFF. Uma abordagem para identificação de padrões comportamentais a partir de aplicativos para redes sociais. Proceedings of the XXXV I berian Latin-American Congress on Computational Methods in Engineering - CILAMCE 2014. 2014

9. Paschoal F, Ribeiro GV, Daquer LMA, Mauro RC, Ogasawara ES, Ebecken NFF. Identificação de padrões comportamentais de usuários de aplicativos sociais para a predição do comportamento saudável do usuário. Proceedings of the XXXVIII Iberian Latin-American Congress on Computational Methods in Engineering - CILAMCE 2016. 2016.

10. Maksimovic M, Vujovic V, Perisic B. A Custom Internet of Things Healthcare System. Atas da $10^{a}$ Conferência Ibérica de Sistemas e Tecnologias de Informação - CISTI 2015. 2015;1:653-8.

11. Barkley JE, Lepp A, Santo A, Glickman E, Dowdell B. The relationship between fitness app use and physical activity behavior is mediated by exercise identity. Comput Hum Behav. 2020;108:106313

12. Paschoal F, Ribeiro GVS, Daquer LMA, Ebecken NFF. Proposta de identificação da evolução temporal de uso de aplicativos sociais para a definição de padrões comportamentais dos usuários. Proceedings of the XXXVI Iberian Latin-American Congress on Computational Methods in Engineering - CILAMCE 2015. 2015.

13. Paschoal F, Ribeiro GVS, Daquer LMA, Mauro RC, Ogasawara E. FitRank - Desenvolvimento de aplicativo para a identificação de padrões comportamentais de atividades físicas a partir de aplicativos para redes sociais. Proceedings of the XXXVI Iberian Latin-American Congress on Computational Methods in Engineering - CILAMCE 2015. 2015.

14. Canabrava K, Amorim P, Miranda V, Priore S, Franceschini S. Comportamento sedentário e risco cardiovascular em crianças: uma revisão sistemática. Rev Bras Med Esporte. 2019;25(5):433-41.

15. Morris M, Consolvo S, Munson SA, Patrick K, Tsai J, Kramer ADI. Facebook for health: opportunities and challenges for driving behavior change. Proceeding CHI EA '11 CHI '11 Extended Abstracts on Human Factors in Computing Systems (nov.). 2011:443-6.

16. Borel WP, Elias Filho J, Diz JBM, Moreira PF, Veras PM, Catharino LL, et al. Prevalência de lesões em corredores de rua amadores brasileiros: metanálise. Rev Bras Med Esporte. 2018;25(2):161-7.

17. Costa M, Dias JMC, Fernandes RM, Sabino GS, Anjos MTS, Felício DC. Prevalência e fatores associados às lesões em corredores amadores: um estudo transversal. Rev Bras Med Esporte. 2019;26(4):215-9.

18. Silva A, Fermino R, Lopes A, Alberico C, Reis R. Distância até as academias ao ar livre, uso das estruturas 
e atividade física em adultos. Rev Bras Med Esporte. 2017;24(2):157-61.

19. Felipe J, Rodrigues MVP, Ferreira AD, Fonseca ES, Ribeiro GGS, Arana ARA. Atividade física e ambiente: a influência dos parques verdes urbanos na saúde. Rev Bras Med Esporte. 2019;25(4):305-9.

20. Silva AAP, Camargo EM, Silva AT, Silva JSB, Hino AAF, Reis RS. Caracterização das atividades físicas realizadas por adolescentes de Curitiba, Brasil. Rev Bras Med Esporte. 2019;25(3):211-5.

21. Geraldes AAR, Silva WB, Balikian Júnior P, Pereira PMG. Efeitos da caminhada sobre o estado de humor de idosos fisicamente ativos. Rev Bras Med Esporte. 2018;25(1):63-6.

22. Anjos $L$, Silva $B$, Wahrlich V. Nível de atividade física e gasto energético avaliados por acelerometria em idosos brasileiros. Rev Bras Med Esporte. 2018;25(2):116-20.

23. Rauber SB, Brandão PS, Moraes JFVN, Madrid B, Barbosa DF, Simões HG, et al. Consumo de oxigênio e gasto energético durante e depois de brincadeiras de rua, vídeo games ativos e tv. Rev Bras Med Esporte. 2018;24(5):338-42.

24. Fochesatto C, Gaya A, Brand C, Mota J, Bandeira DR, Lemes VB, et al. Sono e saúde mental infantil: papel da atividade física e aptidão cardiorrespiratória. Rev Bras Med Esporte. 2019;26(1):48-52.

25. Gorzelitz JS, Malecki KM, Cadmus-Bertram LA. Awareness of Physical Activity Guidelines Among Rural Women. Am J Prev Med. 2020;59(1):143-5.

26. Laux R, Corazza S. Melhora do tempo de reação após intervenção com exercícios físicos no ambiente de trabalho. Rev Bras Med Esporte. 2019;25(6):515-9.

27. Carneiro L, Gomes AR. Fatores pessoais, desportivos e psicológicos no comportamento de exercício físico. Rev Bras Med Esporte. 2015;21(2):127-32.

28. Jaafar Z, Murugan A. Validação de aplicativo gratuito de smartphone para monitoramento da frequência cardíaca durante exercício em esteira. Rev Bras Med Esporte. 2019;25(2):112-5.

29. Nikolic M, Jovanovic R, Stankovic A. Características da atividade física de adolescentes sérvios saudáveis. Rev Bras Med Esporte. 2019;26(1):30-3.

30. Palmeiro E, Valeiro M, Villarino M. Sobrepeso em escolares e associação com a prática de atividade física e hábitos parentais. Rev Bras Med Esporte. 2019;25(4):290-4. 